\title{
37. LATE PLIOCENE AND EARLY PLEISTOCENE SILICOFLAGELLATES AND EBRIDIANS FROM DSDP SITE 378 IN THE AEGEAN BASIN, NORTH OF CRETE
}

\author{
Herbert Stradner, Geological Survey of Austria, Rasumofskygasse 23, A-1031 Wien, Austria \\ and \\ Alfred Bachmann, Putzendoplergasse 22/51/6, A-1232 Wien, Austria
}

\begin{abstract}
Five samples of late Pliocene and two of early Pleistocene age recovered at Site 378 north of the island of Crete were examined for their contents of siliceous remains of marine flagellates.

Twelve species are illustrated and described. The siliceous assemblages consist mainly of diatoms, radiolarians, and silicoflagellates of the family Dictyochidae with rare ebridians and some endoskeletal dinoflagellates. One new species is introduced: Dictyocha aegea. The species distribution in each of the seven samples is expressed in percentages based on counts of 400 specimens per sample. Paleotemperatures are reconstructed by means of the Dictyocha/Distephanus-ratio as described by Mandra and Mandra (1972). The assemblages of Core 5 can be assigned to the Distephanus octogonus Zone of Perch-Nielsen (1975a, b) and the assemblages of Core 8 to the Distephanus boliviensis Zone of Bukry (1976).
\end{abstract}

\section{INTRODUCTION}

Comparatively few deep sea cores from the Mediterranean Sea still contain siliceous remains (diatoms, radiolarians, silicoflagellates). This seems to be the result of $\mathrm{SiO}_{2}$ solution before and after sedimentation. It depends on the degree of $\mathrm{SiO}_{2}$ saturation of the water column through which the siliceous shells and skeletons have to sink on their passage from the biotope down into the thanatocoenosis of the sediment. Only if there is a high degree of $\mathrm{SiO}_{2}$ saturation will the diatom shells and silicoflagellate skeletons not be dissolved (Schrader, 1970). At Site 378, north of Crete, such conditions apparently have been present and have favored the deposition and preservation of siliceous fossils. Fortunately also calcareous nannofossils are preserved, thus making age determinations possible.

\section{PREPARATION TECHNIQUE}

The core samples, of about $1 \mathrm{cc}^{3}$ each, were treated with hydrochloric acid to remove the calcareous fraction. After repeated rinsing with distilled water, the residues were cleaned with hot concentrated sulfuric acid to which, after a couple of hours, some dry saltpeter (potassium nitrate) was added as bleaching agent. After repeated rinsing of the residue with distilled water and centrifuging, strew slides were made and mounted with Caedax (by Merck, refracting index 1.55). These permanent slides, 10 for each sample, were studied with a Zetopan light microscope (Reichert, Austria). The silicoflagellates of Plates 1 and
2 and Figure 1 were photographed on 35-mm Agfa Copex film. The two scanning electron-micrographs of Dictyocha aegea were taken with the ISI Super MiniSEM II by Ing. R. Meindl through the courtesy of the OEWAG Instrumentation in Vienna.

\section{SYSTEMATIC DESCRIPTIONS}

Following the "Annotated Index of Fossil and Recent Silicoflagellates and Ebridians etc." by Loeblich et al., 1968, the silicoflagellates and ebridians described here are considered as phytoplankton.

\section{Phylum CHRYSOPHYCOPHYTA Class CHRYSOPHYCEAE \\ Subclass SILICOFLAGELLATOPHYCIDAE \\ Order SIPHONOTESTALES \\ Family DICTYOCHIDAE}

Genus DICHTYOCHA Ehrenberg, 1837

\section{Dictyocha aegea n. sp.}

(Plate 1. Figures 12-16; Figure 1)

Derivation of name: from the Aegean Sea.

Original description: A silicoflagellate species with the general features of Dictyocha fibula, from which it differs by the four-lobed, angular outline of the basal ring and its compressed flanks. The basal spines in direction of the major axis are short, less than onethird of the greater diameter of the basal ring and have additional pikes near them, which emphasize the angular outline of the basal ring. The spines in direction of the minor axis are reduced to the size of longer distal pikes, to about one-eighth of the shorter diameter of the basal ring. At the place where these shorter spines insert, the basal ring appears compressed and in some specimens, even caved in. (Plate 1, Figure 16) At this straight or concave part of the basal ring there can be centripetal knobs or pikes (Plate 1, Figure 15), 


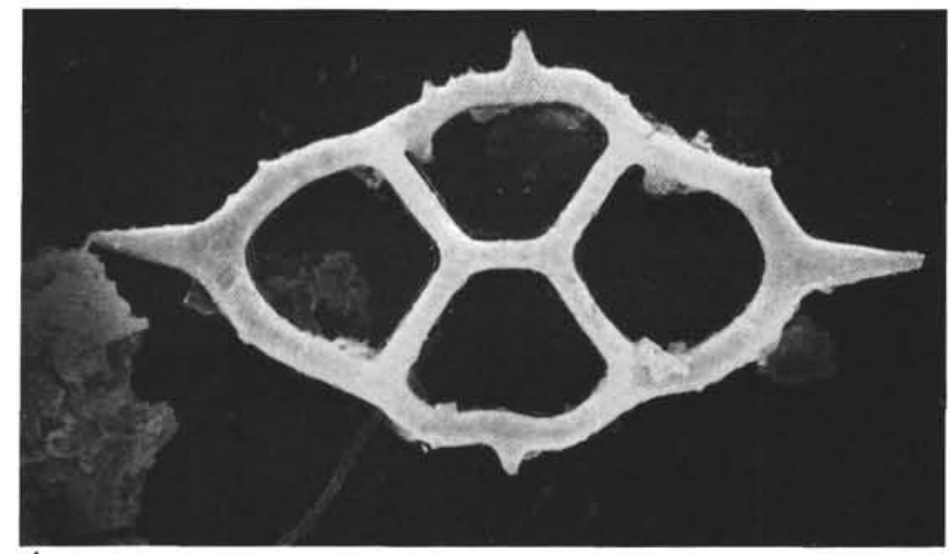

A

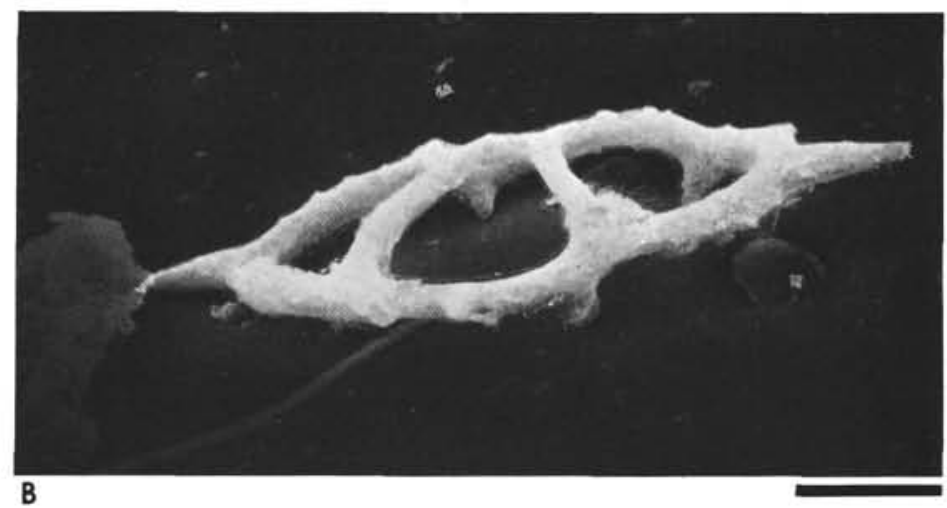

Figure 1. Dictyocha aegea nov. spec. Stradner and Bachmann scanning micrographs of Paratype $X(A)$ plan view $0^{\circ},(B)$ oblique side view $65^{\circ}$; Sample 378-8-1, 114-115 cm. Scale bar: $1 \mathrm{\mu m}$.

which are not basal sustaining pikes in a strict sense. The holotype (Plate 1. Figure 16) and also most of the paratypes have four basal pikes, which point in abapical direction and are inserted near the lateral struts. The apical bar is fibuloid; that is, in the direction of the major axis. Asperoid specimens are extremely rare and thus fall within the normal ratio of variation.

Type locality: Aegean Sea north of Crete, Sample 378-1-114-115 $\mathrm{cm}$

Type stratum: Upper Pliocene, NN 16.

Holotype: Plate 1, Figure 16; Paratypes: Plate 1, Figures 13-15 and Figure 2.

Dimensions: Overall length more than $50 \mu \mathrm{m}$, overall width 30 $\mu \mathrm{m}$; basal ring length approximately $40 \mu \mathrm{m}$, width approximately 25 $\mu \mathrm{m}$.

Deposition of types: Geological Survey of Austria.

Discussion: Similar skeletons have been described by Locker (1974) as Dictyocha varia fa. extensa. Dictyocha varia Locker has the apical bar usually transverse, that is, asperoid or parallel to the direction of the minor axis, and is smaller and less elongate that Dictoycha aegea. Bukry (1973) has shown a specimen with auxiliary distal pikes on the basal ring (Plate 2, Figure 9) from the eastern Pacific Ocean (Sample 157-18,cc) and emphasizes that the presence of distal pikes on the basal ring is not a warmwater character.

\section{Dictyocha fibula Ehrenberg \\ (Plate 1, Figures 3 and 4)}

Dictyocha fibula Ehrenberg, 1838 (1840), p. 129, pl. 4, fig. 16; Marshall, 1934, p. 627, fig. 3; p. 628, fig. 40 a-c; Frenguelli, 1935, pl. 1-12; 1938, p. 235, fig. 3; Bachmann, 1964, p. 99-100, pl. 2, fig. 9-11; Ling, 1971, p. 691, pl. 1, fig. 3,4; 1972, p. 161, pl. 25, fig. 1112; Burkry, 1973, p. 826-827, pl. 3, fig. 12.

Siliceous skeletons consisting of a rhombic to lobed basal ring with radial spines at the ends of the major and minor axes and a longitudinal (fibuloid) apical bar supported by four raised lateral arches. Sustaining pikes are inserted in the basal ring near the lateral arches. Also, rare variations of skeletons with a short asperoid apical bar transverse to the major axis of the basal ring (Plate 1, figure 9) can be found. Occasionally, pentagonal and even corbisemoid forms as well as "formae apertae" with open basal ring are seen.

Occurrence: Site 378, Core 5, Site 378, Core 8.

\section{Dictyocha perlaevis Frenguelli \\ (Plate 1, Figures 5, 6, 9-11)}

Dictyocha perlaevis Frenguelli, 1951, p. 279, fig. 4b-c; Loeblich et al., 1968, p. 109, pl. 51, fig. 7, 8, Dumitrica, 1973, p. 848, pl. 3, fig. 8-12; pl. 4, fig. 1, 2, Bukry, 1975, p. 855, pl. 3, fig. 5 (Dictyocha fibula perlaevis); Bukry, 1976, p. 724 , pl. 2, fig. 4 (Dictyocha perlaevis perlaevis).

This species is distinguished from Dictyocha fibula by the pronounced four-lobed basal ring, the more obtuse angle between the apical bar and the supporting struts, its larger size, and the relatively shorter radial spines. Bukry also distinguishes as subspecies $D$. perlaevis delicata with a very thin apical bar and lateral struts.

Occurrence: Site 378, Core 5 and Site 378, Core 8. According to Bukry (1975) it is common in low-latitude assemblages.

\section{Dictyocha stapedia aspinosa (Haeckel) Bukry (Plate 1, Figures 1, 2, 7, 8)}

Dictyocha stapedia Haeckel, 1887, p. 1561, pl. 101, fig: 10-12; Loeblich et al., 1968, p. 115, pl. 22, fig. 1-3; Dictyocha stapedia aspinosa Bukry, 1976, p. 724, pl. 2, fig. 6-9.

Basal ring broadly rhombic, slightly lobed with four basal spines, which can be of equal length. Apical bar fibuloid that is in the direction of the major axis, without spire. Four basal auxiliary pikes, which are slightly offset.

Occurrence: Site 378, Core 5 and Site 378, Core 8. 


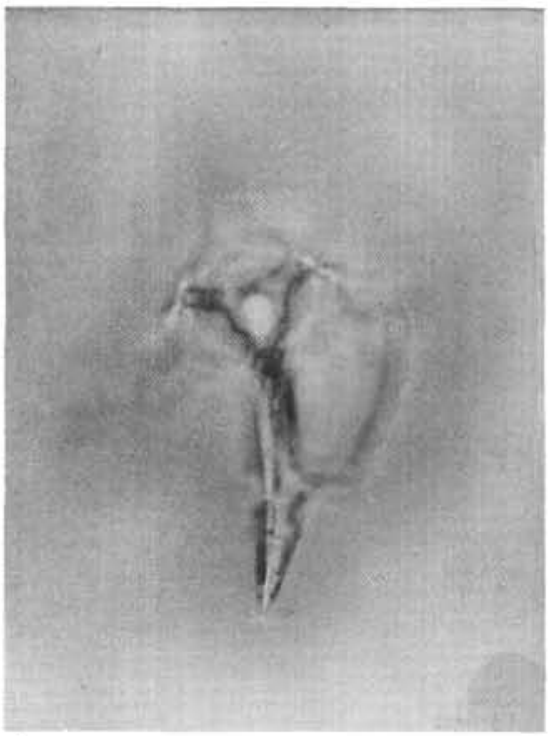

A
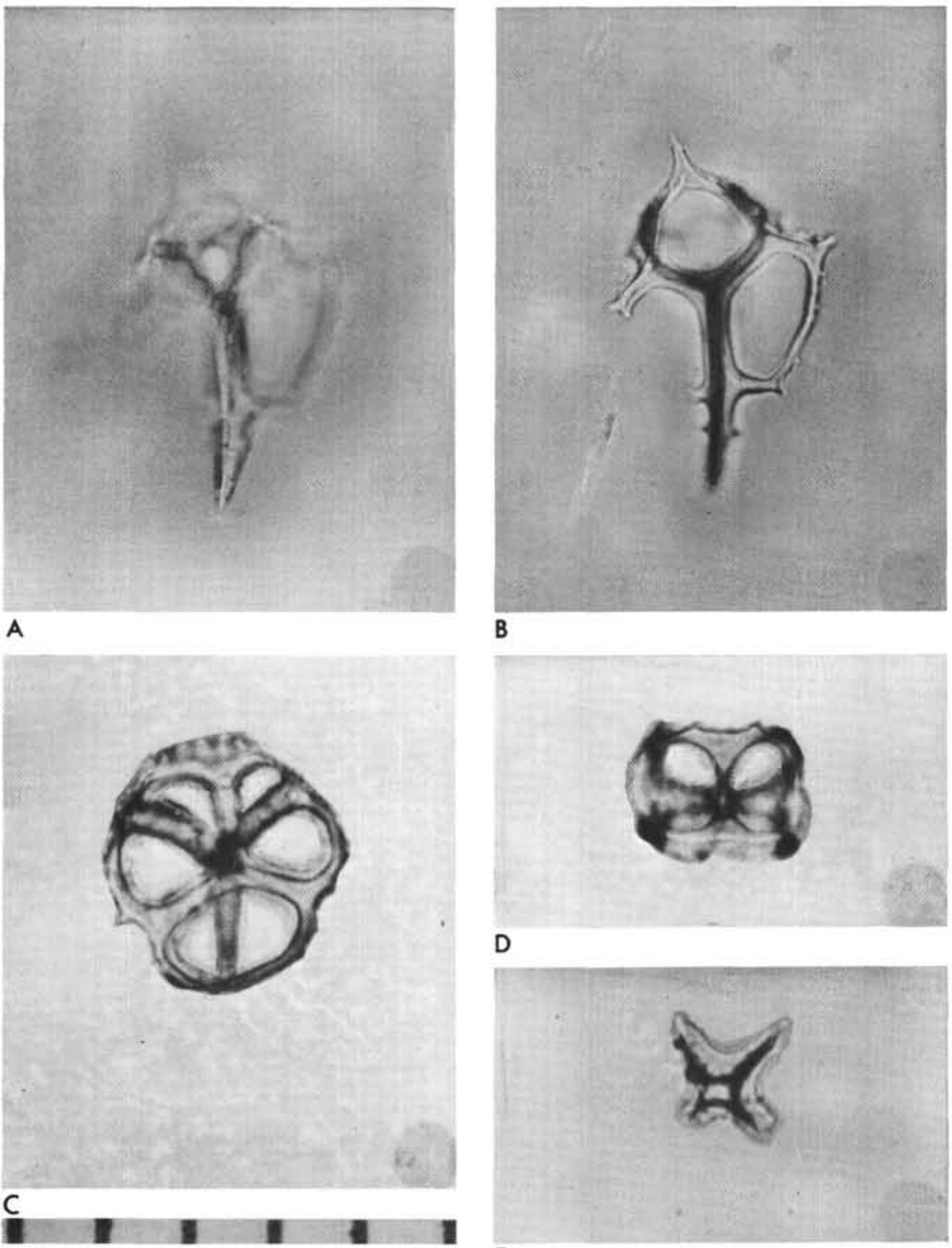

B

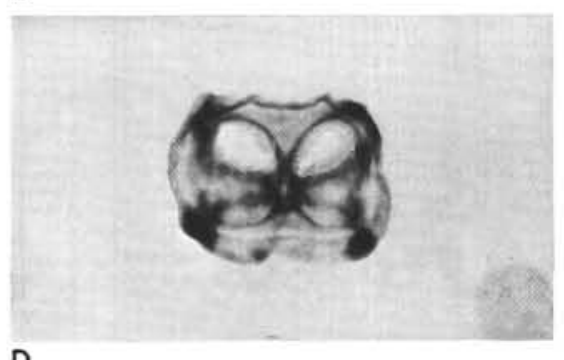

D

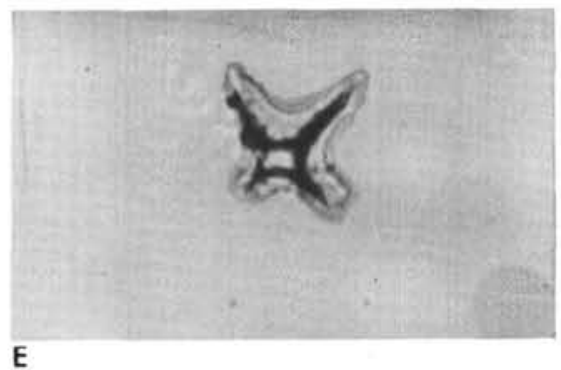

Figure 2. Ebridians photomicrogaphs $(A, B)$ Hermesium adriaticum Zacharias (A) high focus, (B) low focus; Sample 378-8-2, 20-21 cm, Hypotype A/N. (C) Ebriopsis antiqua (Schulz) Hovasse; Sample 378-8-1, 20-21 cm, Hypotype $B / C$, (D) Ammodochium rectangulare(Schulz) Deflandre; Sample 378-8-1, 20 $21 \mathrm{~cm}$, Hypotype $B / G,(E)$ Actiniscus tetrasterias Ehrenberg, apical view, Sample 378-8-1, 114-115 cm, Hypotype B/A. Micrometer scale photographed under identical optical conditions (1 partition $=10 \mu \mathrm{m})$.

Genus DiSTEPHANUS Stöhr, 1880

\section{Distephanus boliviensis (Frenguilli) Bukry and Foster} (Plate 2, Figures 9, 10)

Dictyocha boliviensis Frenguelli, 1940, p. 44, fig. 4; Syn. Dictyocha glabra Frenguelli, 1941; Loeblich et al., 1968, p. 83, pl. 9, fig. 3.

Distephanus boliviensis (Frenguelli) Bukry and Foster, 1973, p. 827, pl. 4, fig. 1-3.

Distephanus boliviensis boliviensis (Frenguelli) Bukry, 1976, p. 725.

Especially large skeletons of a general structure similar to Distephanus speculum, from which it differs not only by its overall dimension, but also by the large basal pikes and by its tendency to form cannopiloid or otherwise extraordinary apical rings. Basal rings usually six-sided, but also five-sided and seven-sided rings do occur. In the Aegean assemblages of Site 378 , Core 8 the basal spines along the main axis are more pronounced than hitherto described.

Occurrences: Site 378, Core 8; rare in Site 378, Core 5.
Distephanus octogonus (Ehrenberg) Dumitrica (Plate 2, Figure 16)

Mesocena? octogona Ehrenberg, 1843

Distephanus octogonus (Ehrenberg) Dumitrica 1973, p. 908, pl. 12. figs. 15-19.

Octactis pulchra Schiller, 1925 (fide Loeblich et al., 1968, p. 59, pl. 32, fig. 1)

Octactis pulchra Schiller; Bukry and Foster 1973, p. 829, pl 6, fig. 1112.

Delicate oval basal rings with normally eight short symmetrical radial spines and traces of lateral arches. No basal spines.

Occurrences: In living populations in the Adriatic Sea (Schiller). According to Dumitrica it is restricted to Quaternary (DSDP Sites 127 and 128 in the eastern Mediterranean). Common in late Pleistocene and Holocene core samples from the Black Sea (Bukry), rarely in Quaternary samples in the eastern Pacific (Bukry and Foster, 1973). 
Distephanus speculum (Ehrenberg) Haeckel

(Plate 2, Figures 1-8, 11, 12)

Dictyocha speculum Ehrenberg, 1839, p. 129.

Distephanus speculum (Ehrenberg) Haeckel, 1887, p. 1565; Marshall, 1934, p. 626, fig. 2; Ling, 1970, pl. 19, fig. 13; Fuji and Bachmann 1970, p. 78, pl. 3, fig. 7. 8, pl. 4, fig. 3, 4; Bukry and Foster, 1973, p. 825 , pl. 5, fig. 8; Dumitrica. 1972, p. 908 , pl. 10, fig. 4. 6-11. pl. 11, fig. 2, 4, 6, 8, pl. 12, fig. 1-14; Perch-Nielsen, 1975, p. 688, pl. 6 , fig. 12,$13 ;$ pl. 7 , fig. 16, 23.

Siliceous skeletons with hexagonal basal and apical ring, occasionally also pentagonal and rarely heptagonal. Along one axis the basal spines are longer. The apical ring can be either smooth or decorated with six apical pikes. Such skeletons with a crown-shaped apical ring have been described as $D$. speculum var. aculaetus (Ehrenberg) Lemmermann, 1908 (p. 31, fig. 102).

In the early Pleistocene of Site 378, Core 5 the small and delicate Distephanus speculum and especially larger Distephanus boliviensis are rare. In the upper Pliocene both species co-occur with intermediate forms.

Occurrence: Site 378. Core 5 and Site 378, Core 8. Cold water indicator.

\section{Genus PARADICTYOCHA Frenguelli \\ Paradictyocha circulus (Ehrenberg) Dumitrica}

(Plate 2, Figures 13-15)

Dictyocha circulus Ehrenberg, 1840, p. 208.

Mesocena circulus Ehrenberg, 1844, p. 65; Glezer, 1966, p. 306, pl. 29. fig. 8; Martini, 1971, p. 1697, pl. 1. fig. 17; Bukry and Foster, 1973, p. 828, pl. 5, fig. 9 .

Paradictyocha circulus (Ehrenberg) Dumitrica, 1973, p. 855, pl. 9, fig. 7-10.

Subcircular to oval rings with short irregularly spaced spines in centrifugal direction, at one point of the periphery either straightened or caved in. Also open skeletons (formae apertae) were found.

Occurrence: Less common in Site 378, Core 8 and rare in Site 378, Core 5 .

Compared to the above silicoflagellates of the order Siphonotestales the following siliceous skeletons of the order Stereotestales only play a minor role in the composition of the siliceous assemblages in Site 378 , Core 8 . They only constitute a few percent of the flagellates with siliceous skeletons.

\section{Order STEREOTESTALES}

Family EBRIOPSIDAE

Genus EBRIOPSIS Hovasse, 1932

Ebriopsis antiqua (Schulz) Hovasse

(Figure 2)

Ebria antiqua Schulz, 1928, p. 273.

Ebriopsis antiqua (Schulz) Hovasse. Rampi, 1942, p. 290, fig. 1; Tsumura, 1963, p. 75, pl 2. fig. 6; Perch-Nielsen, 1975, p. 880, pl 4, fig. 15.

Siliceous skeletons with a central structure formed of six rods which are arranged in such a way as to form two alternating " $\mathrm{Y}$ "s. The distal ends of these rods are bifurcated and combine to form a closed ring. $\mathrm{cm}$.

Occurrence: Rare in Sample Site 378, Core 8, Section 1, 20-21

Genus AMMODOCHIUM Hovasse, 1932

Ammodochium rectangulare (Schulz) Deflandre

(Figure 2)

Ebria antiqua var. rectangularis Schulz, 1928, p. 274, fig. 72 a-d. Ammodochium rectangulare (Schulz) Deflandre, 1932, p. 303-305, fig.

1-13; Dumitrica, 1973, p. 935, pl. 2, fig. 6, 7; Perch-Nielsen, 1975,

p. 880 , pl. 4 , fig. 19-28, 30-32, pl. 5, fig. 23-26, pl. 9, fig. 22.

Siliceous skeletons consisting of three parallel proclades, which in the center are united by a triangular plate of three actines and at the apical and antapical end by a ring.

Occurrence: Rare in Sample 378-8-1, 20-21 cm. According to Ling (1973) Ammodochium rectangulare has its last occurrence approximately at the Plio-Pleistocene boundary.
Genus HERMESINUM Zacharias, 1906

Hermesinum adriaticum Zacharia, 1906

(Figure 2)

Hermesinum adriaticum Zacharias 1906, p. Hovasse, 1932, p. fig. 9; Loeblich et al., 1968, fig. 20; pl. 40, fig. 9a-10; Dumitrica, 1973, p. 934, pl. 2, fig. 1-5.

Siliceous asymmetrical skeletons similar to those which were illustrated by Dumitrica who recovered them from Quaternary sediments of DSDP Sites 127 and 128 in the eastern Mediterranean.

Occurrence: Rare in Sample 378-8-2, 20-21 cm.

\section{Endoskeletal Dinoflagellates \\ Family ACTINISCIDAE Kützing \\ Genus ACTINISCUS Ehrenberg \\ Actiniscus tetrasterias Ehrenberg \\ (Figure 2)}

Actiniscus tetrasterias Ehrenberg. 1854, pl. 18, fig. 62; Gemeinhardt, 1931. pl. 10, fig. 8; Dumitrica, 1968, pl. 4, fig. 24; Dumitrica, 1973, p. 822, pl. 3., fig. 15-18, pl. 5, fig. 9; Perch-Nielsen, 1975, p. 882 , pl. 10 , fig. 1 .

Four-rayed convex-concave skeletons with four elevated ridges and a central square structure on the convex distal side.

Occurrence: Rare in Sample 378-8-1, 114-115 cm.

\section{PALEOTEMPERATURES}

In order to estimate the temperature in the Aegean Sea during late Pliocene and early Pleistocene times, the relative abundances of the warm water indicator Dictyocha fibula and the cold water indicator Distephanua speculum were determined. The basic relation of Distephanus-dominated assemblages in cold areas and Dictyocha in warm (Gemeinhardt, 1930) has been verified by prior DSDP drillings (Bukry, 1976). By calculating the Dictyocha/Distephanus ratio (Mandra and Mandra), and comparing it with the water temperature assigned to such ratios by Martini, 1971 (after Yanagisawa, 1943) temperature values as seen in Table 1 were obtained.

These data were calculated assuming that closely related species of Dictyocha fibula (e.g., D. perlaevis, $D$. aegea and D. stapedia aspinosa) and of Distephanus speculum (e.g., D. boliviensis) had similar temperature preferences to those of the extant Dictyocha fibula and Distephanus speculum. Paradictyocha circulus was not considered for lack of information regarding its preferred temperature. As it was not found contributing more than $7 \%$ of the total assemblage, it does not effect the statistics appreciably. The Dictyocha/Distephanus ratio provides convincing evidence that there have been at least two warm episodes in late Pliocene and early Pleistocene times in the Aegean Sea, with an increase of at least $5^{\circ} \mathrm{C}$ in the late Pliocene and presumably more in the early Pleistocene.

\section{REMARKS ON THE PALEOECOLOGY}

The silicoflagellates, which in Core 8 of DSDP Site and Core 5 of Site 378 , only constitute a minor fraction of the siliceous assemblage of marine diatoms, radiolarians, spongue spicules, foraminifera, and the calcareous nannofossils are, like those other groups, indicators of their paleoenvironment. In Site 378 Core 8 we found a low Dictyocha/Distephanus ratio suggesting cool 
TABLE 1

Dictyocha/Distephanus Ratio Based on Percentages of These Species and Their Close Relations After Counts of 400 Specimens From Each Sample (after Martini, 1971)

\begin{tabular}{|c|c|c|c|c|c|c|c|}
\hline & $\begin{array}{l}E \\
\overrightarrow{0} \\
\infty \\
\vec{n}\end{array}$ & 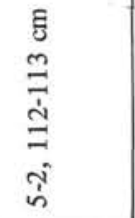 & $\begin{array}{l}\text { है } \\
\vec{\tau} \\
\text { ठे } \\
\dot{\infty} \\
\dot{\infty}\end{array}$ & 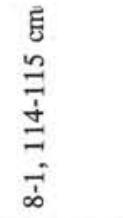 & 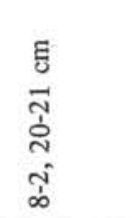 & $\begin{array}{l}\text { हี } \\
\text { Һे } \\
\text { ஸे } \\
\text { ஸे } \\
\infty\end{array}$ & $\begin{array}{l}0 \\
\infty\end{array}$ \\
\hline $\begin{array}{l}\text { Dictyocha fibula } \\
\text { and related species }\end{array}$ & $96 \%$ & $92 \%$ & $29 \%$ & $57 \%$ & $35 \%$ & $38 \%$ & $45 \%$ \\
\hline $\begin{array}{l}\text { Distephanus speculum } \\
\text { and related species }\end{array}$ & $4 \%$ & $7 \%$ & $66 \%$ & $36 \%$ & $58 \%$ & $62 \%$ & $54 \%$ \\
\hline Paradictyocha circulus & - & $1 \%$ & $5 \%$ & $7 \%$ & $7 \%$ & - & $1 \%$ \\
\hline $\begin{array}{l}\text { Dictyocha/Distephanus } \\
\text { ratio }\end{array}$ & $24: 1$ & $13: 1$ & $\sim 1: 2$ & $\sim 1.6: 1$ & $\sim 1: 1.7$ & $\sim 1: 1.6$ & $1: 1.2$ \\
\hline $\begin{array}{l}\text { Paleotemperature after } \\
\text { Yanangisawa, } 1943 \\
\text { and Martini, } 1971\end{array}$ & $25-30^{\circ} \mathrm{C}$ & $25-30^{\circ} \mathrm{C}$ & $10-15^{\circ} \mathrm{C}$ & $20-25^{\circ} \mathrm{C}$ & $15-20^{\circ} \mathrm{C}$ & $15-20^{\circ} \mathrm{C}$ & $15-20^{\circ} \mathrm{C}$ \\
\hline
\end{tabular}

seawater, with a "warm-peak" at Sample 378 Core 8 Site 1, 114-115 cm. We also found obvious differences in the length of the radial spines within the populations of Distepanus speculum; long spines are indicative of cold water, short spines of warm water. The presence of long spined and short spined forms in the sample may be caused either by seasonal climatic instability or by periods of upwelling. Upwelling of cold seawater favors the growth of diatoms and silicoflagellates by increase in supply of $\mathrm{SiO}_{2}$. As shown by Hekel (1973), the influx of rivers also can favor micro-organisms producing silicous shells. We thus assume that during the late Pliocene (NN 16) the seawater in the Aegean was generally cool with intermittent warm peaks. During the early Pleistocene the seawater became markedly warmer as indicated by the higher Dictyocha/Distephanus rate. The cold water species Distephanus speculum is rare, being less than $10 \%$ of the silicoflagellate assemblage.

\section{ZONATION}

Two marker fossils can be used to assign the silicoflagellate assemblages to successive zones: Distephanus ocotogonus and Distephanus boliviensis. Core 378-8 evidently still lies within the acme of Distephanus boliviensis and thus can be assigned to the $D$. boliviensis Zone (Bukry, 1976) of late Pliocene age. Core 3785, with Distephanus octogonus can be assigned to Distephanus octogonus Zone (Perch-Nielsen, 1975) as it was deposited after the first occurrence of the namegiving species at or slightly below the Plio-Pleistocene boundary.

\section{ACKNOWLEDGMENTS}

For supplying the raw samples from DSDP Site 378, thanks are due to the Co-Chiefs of Leg 42A, Prof. Dr. Hsü and Dr. L. Montadert, and to Dr. C. Müller, the nannofossil specialist of Leg 42, who aboard ship first discovered the silicoflagellate assemblages. For permission to use the laboratory facilities of the Geological Survey of Austria we thank Director Prof. Dr. F.-Ronner and vice-Director Dr. T. Gattinger. For critical reading of the manuscript we thank Dr. K. Perch-Neilsen, Zürich.

\section{REFERENCES} 1968

All references prior to 1968 are to be found in Loeblich et al.,

Bachmann, A., 1970. Flagellata (Silicoflagellata): Catalogus Fossilium Austriae. Öst. Akad. Wiss., p. 1-28.

Bukry, D., 1976 Silicoflagellate and coccolith stratigraphy, Southeastern Pacific Ocean, DSDP Leg 34. In Yeats, R. S., Hart, S. R., et al., Initial Reports of the Deep Sea Drilling Project, Volume 34: Washington (U.S. Government Printing Office), p. 715-736.

Bukry, D. and Foster, J. H., 1973. Silicoflagellate and Diatom Stratigraphy, Leg 16, Deep Sea Drilling Project. In Van Andel, T. H., Heath, G. R., et al., Initial Reports of the Deep Sea Drilling Project, Volume 16; Washington (U.S. Government Printing Office), p. 815-871.

Dumitrica, P., 1972. Miocene and Quaternary silicoflagellates in sediments from the Mediterranean Sea In Ryan, W. B. F., Hsü, K. J., et al., Initial Reports of the Deep Sea Drilling Project, Volume 13: Washington (U.S. Government Printing Office), p. 902-943.

1973. Cenozoic endoskeletal dinoflagellates in southwestern Pacific sediment cored during Leg 21 of the DSDP. In Burns, R. E., Andrews, J. E., et al., Initial Reports of the Deep Sea Drilling Project, Volume 21: Washington (U.S. Government Printing Office), p. 819835.

Hekel, H., 1973. Late Oligocene to Recent nannoplankton from the Capricorn Basin (Great Barrier Reef Area): Palaeontol. Paper 33, Geol. Surv. Queensland 359.

Ling, H. Y., 1970. Silicoflagellates from Central North Pacific core sediments: Am. Paleontol. Bull., v. 58, p. 83-129.

Loeblich, A. R., III, Loeblich, L. A., Tappan, H., and Loeblich, A. R., Jr., 1968. Annotated index of fossil and recent silicoflagellates and ebridians with descriptions and illustrations of validly proposed taxa: Geol. Soc. Am. Mem. 106.

Mandra, Y. T., 1968. Silicoflagellates from the Cretaceous, Eocene, and Miocene of California, U.S.A.: Calif. Acad. Sci. Proc., v. 36, p. 231-277.

Mandra, Y. T. and Mandra, H., 1972. Paleoecology and taxonomy of silicoflagellates from an upper Miocene diatomite near San Felipe, Baja California, Mexico. Occas. Pap. Calif. Acad. Sci., p. 2-35. 
Martini, E., 1971. Neogene silicoflagellates from the Equatorial Pacific. In Winterer, E. L., Riedel, W. R., et al., Initial Reports of the Deep Sea Drilling Project, Volume 7: Washington (U.S. Government Printing Office), p. 1695 1707.

Perch-Nielsen, K. 1975a. Late Cretaceous to Pleistocene silicoflagellates from the Southern Southwest Pacific, DSDP, Leg 29. In Kennett, J. P., Houtz, R. E., et al., Initial Reports of the Deep Sea Drilling Project, Volume 29: Washington (U.S. Government Printing Office), p. 677-721. 1975b. Late Cretaceous to Pleistocene Archaeomonads, Ebridian endoskeletal dinoflagellates, and other siliceous microfossils from the Subantarctic Pacific, DSDP, Leg 29: In Kenneth, J. P , Houtz, R. E., et al., Initial Reports of the Deep Sea Drilling Project, Volume 29. Washington (U.S. Government Printing Office), p. 873907.

Schrader, H.-J., 1970. Selektive Auflösung planktischer Diatomeen im Seegebiet zwischen $15-43^{\circ}$ nördlicher Breite und $8-30^{\circ}$ westlicher Länge; Second Plankt. Conf. Proc., Roma 1970, p. 1139-1147. 



\section{PLATE 1}

Silicoflagellates, Photomicrographs: $725 \times$ Micrometer scale photographed under identical optical conditions $(1$ partition $=10 \mu \mathrm{m})$

Figures 1,2 Dictyocha stapedia Haeckel var. aspinosa Bukry.

1. Sample 378-8-2, 20-21 cm. Hypotype O/A.

2. Sample $378-5-1,81 \mathrm{~cm}$. Hypotype C/M.

3. Sample 378-8-2, 20-21 cm. Hypotype F/O.

Figures 3,4 Dictyocha fibula Ehrenberg. Sample 378-8-2, 20-21 cm. Hypotype G/A and Hypotype A/I.

Figure $5 \quad$ Dictyocha perlaevis Frenguelli. Sample 378-8-1, 114-115 cm. Hypotype A/D.

Figure $6 \quad$ Dictyocha perlaevis Frenguelli. Sample 378-5-1, $81 \mathrm{~cm}$. Hypotype C/M.

Figure 7 Dictoycha stapedia Haeckel var. aspinosa Bukry Sample 378-5-2, 112-113 cm. Hypotype G/R.

Figure 8 Dictyocha stapedia Haeckel var. aspinosa Bukry. Sample 378-8-1, 20-21 cm. Hypotype A/P.

Figures 9-11 Dictyocha perlaevis Frenguelli, asperoid forms.

9. Sample 378-8-1, 114-115 cm. Hypotype G/A.

10. Sample $378-5-1,81 \mathrm{~cm}$. Hypotype H/R.

Figure 12 Dictyocha aegea n. sp., asperoid form Sample 378-8-1, 114-115 cm. Paratype E/D.

Figures 13-16 Dictyocha aegea n. sp. Stradner and Bachmann. Sample 378-8-1, 114-115 cm.

13. Paratype G/L

14. Paratype E/A

15. Paratype E/B

16. Holotype F/E 
PLATE 1
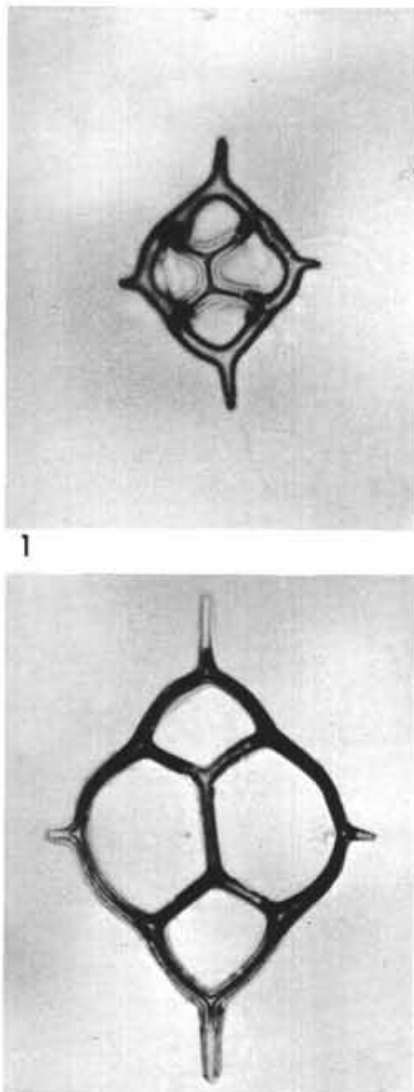

5

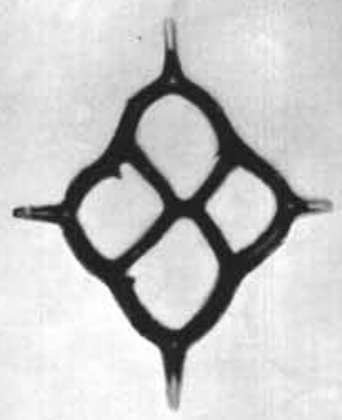

9

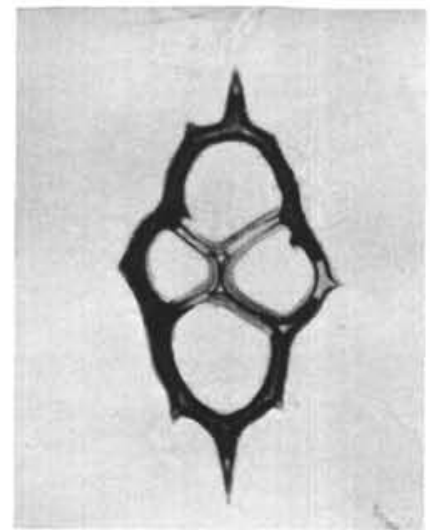

13

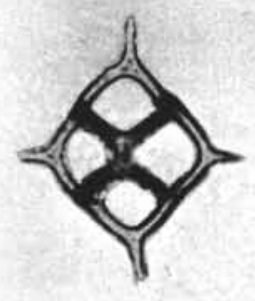

2

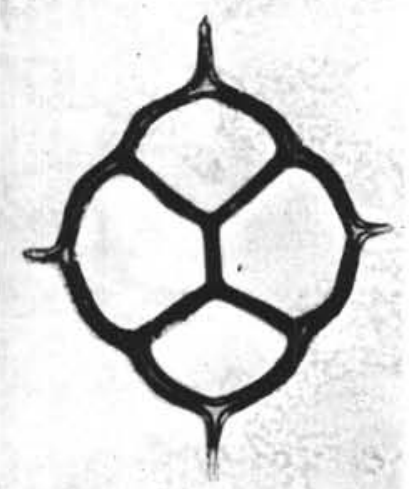

6

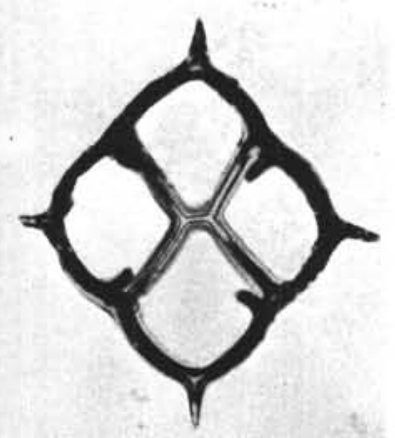

10

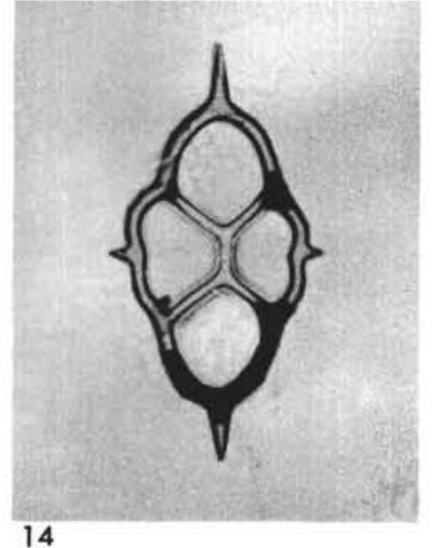

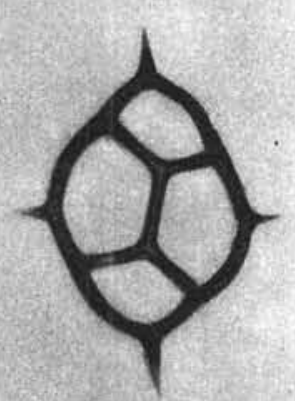

3

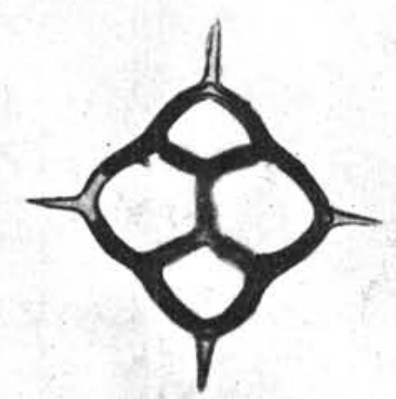

7

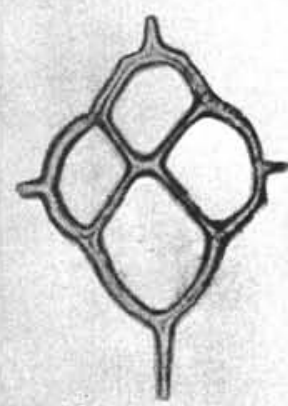

11

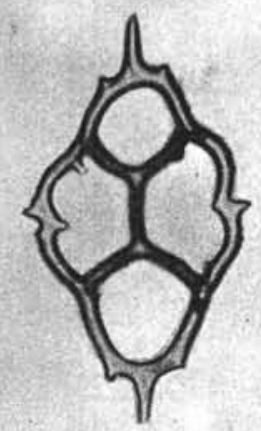

15
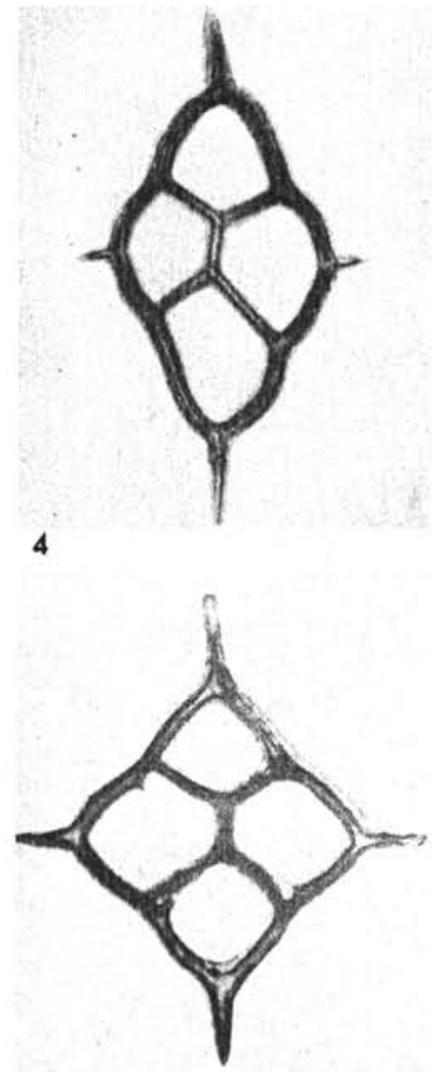

8

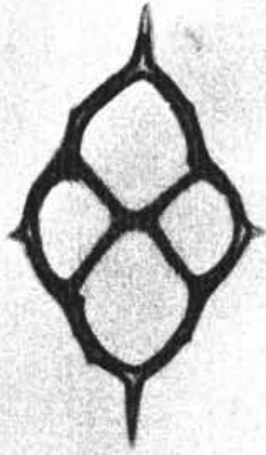

12

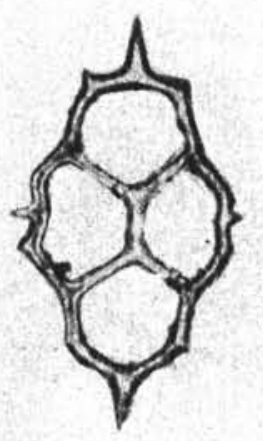

16 


\section{PLATE 2}

Silicoflagellates, Photomicrographs: $725 \times$

Micrometer scale photographed under identical optical conditions $(1$ partition $=10 \mu \mathrm{m})$

Figures 1, 2 Distephanus speculum (Ehrenberg) Haeckel. Sample 378-8-2, 20-21 cm. Hypotype A/U.

1. High focus.

2. Low focus.

Figures 3, 4 Distephanus speculum (Ehrenberg) Haeckel forma coronata Schulz. Sample 378-8-2, 20-21 cm. Hypotype E/A.

3. High focus.

4. Low focus.

Figure 5 Distephanus speculum (Ehrenberg) Haeckel. Double skeleton in side view.

Sample 378-8-2, 20-21 cm. Hypotype A/O.

Figure 6 Distephanus speculum (Ehrenberg) Haeckel var. pentagonus Lemmermann.

Pentagonal forma aperta.

Sample 378-8-1, 20-21 cm. Hypotype G/L.

Figure 7 Distephanus speculum (Ehrenberg) Haeckel forma coronata Schulz.

Hexagonal forma aperta.

Sample 378-8-2, 20-21 cm. Hypotype A/R.

Figure 8 Distepanus speculum (Ehrenberg) Haeckel forma pseudofibula Schulz.

Sample 378-8-2, 20-21 cm. Hypotype A/B.

Figure 9

Distephanus boliviensis (Frenguelli) Bukry and Foster.

Hexagonal specimen with pentagonal apical ring. Sample 378-5-2, 112-113 cm. Hypotype O/C.

Figure 10 Distephanus boliviensis (Frenguelli) Bukry and Foster; hexagonal specimen with "binocular", apical ring.

Sample 378-5-2, 112-113 cm. Hypotype F/D.

Figure 11 Distephanus speculum (Ehrenberg) Haeckel. Hexagonal specimen with "binocular" apical ring. Sample 378-8, CC. Hypotype B/C.

Figure 12 Distephanus speculum (Ehrenberg) Haeckel. Heptagonal specimen.

Sample 378-8-2, 20-21 cm. Hypotype B/F.

Figures 13-15 Paradictyocha circulus (Ehrenberg) Dumitrica. 13. Sample $378-8-2,20-21 \mathrm{~cm}$. Hypotype G/L. 14. Sample $378-8-1,20-21 \mathrm{~cm}$. Hypotype D/J. 15. Sample $378-8-2,20-21 \mathrm{~cm}$. Hypotype E/B.

Figure 16 Distephanus octogonus (Ehrenberg) Dumitrica. Sample 378-5-1, $81 \mathrm{~cm}$. Hypotype C/L. 
PLATE 2

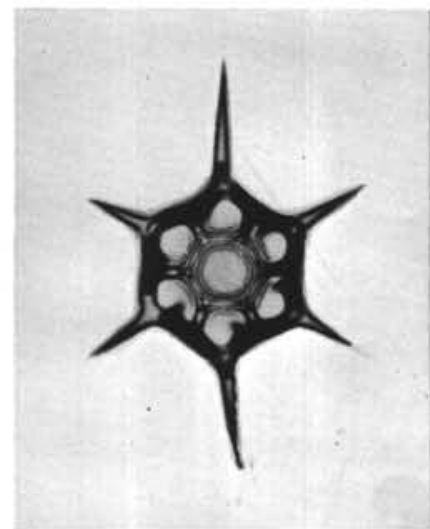

1

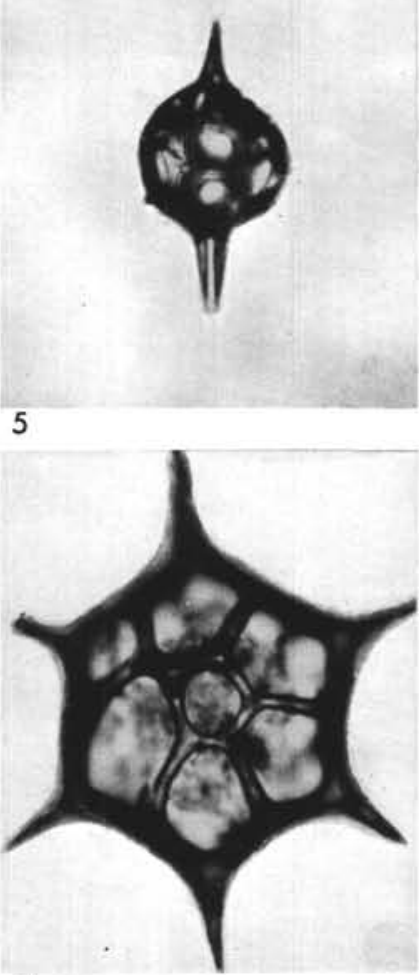

9

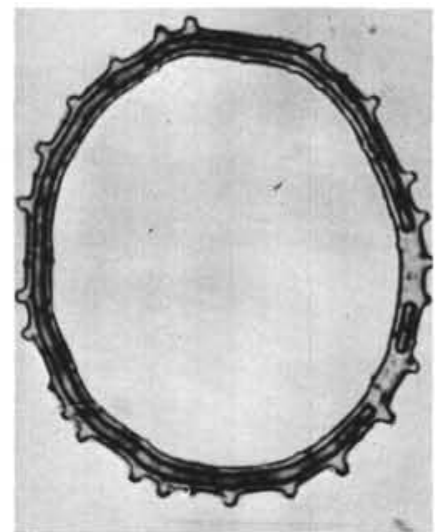

13
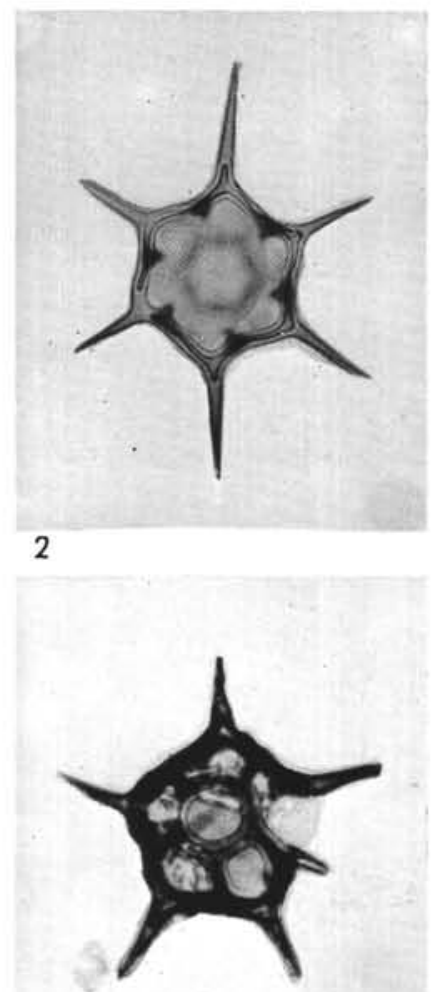

6

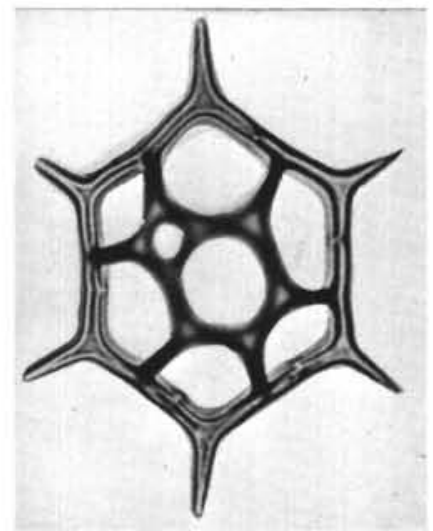

10

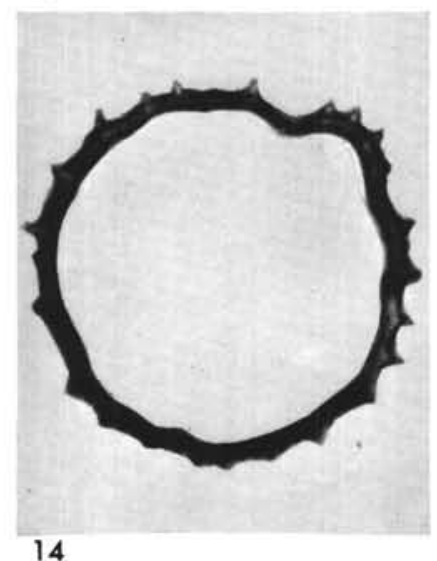

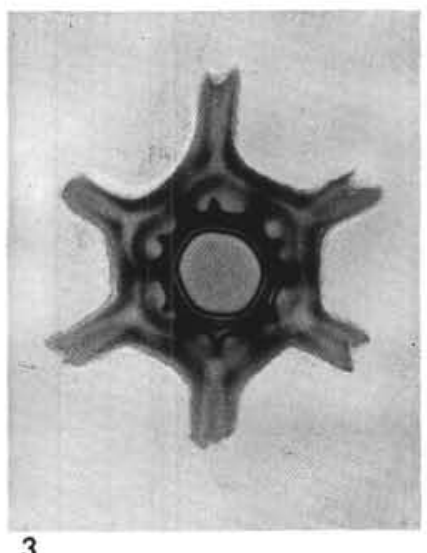

3

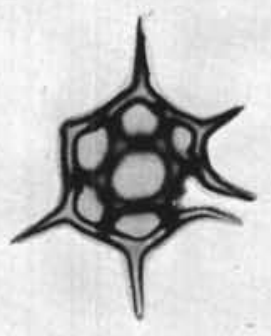

7

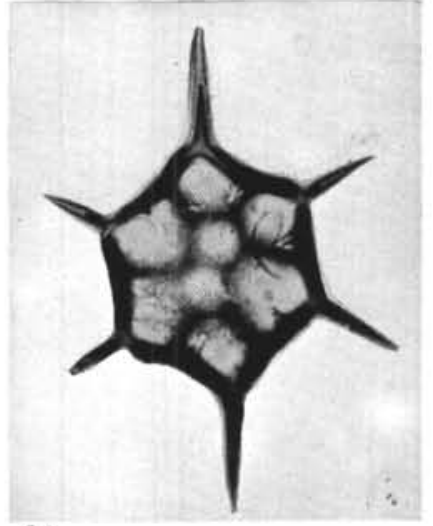

11

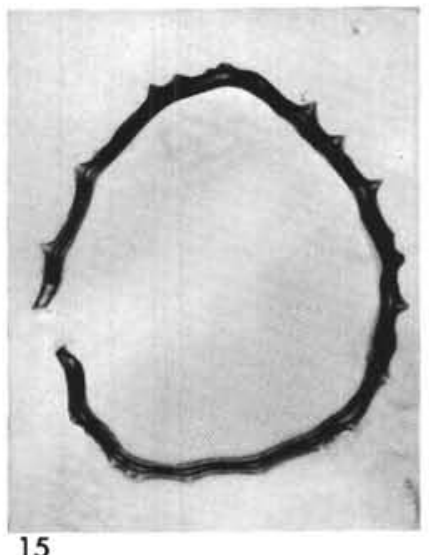

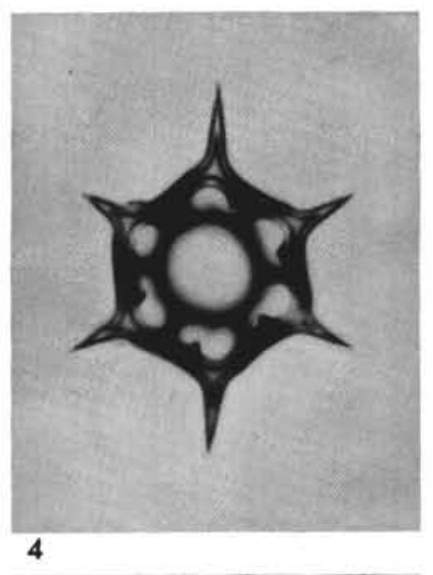

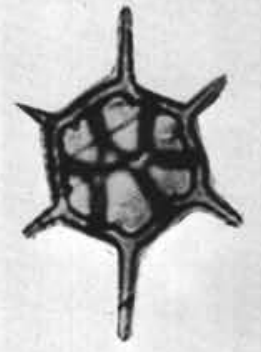

8

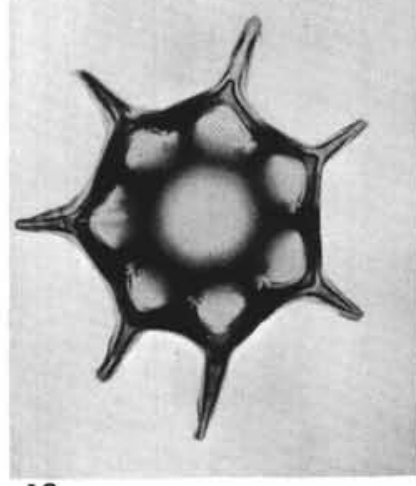

12

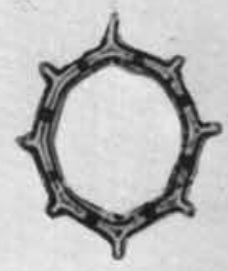

